4. Mykhasiuk O. K. Uprovadzhennia hromadsko derzhavnoho upravlinnia zakladom zahalnoi serednoi osvity u konteksti zakonodavchykh zmin [The implementation of the public-state management of general secondary educational institutions in contexsts of legislative changes]. Imidzh suchasnoho pedahoha. 2017. № 8 (117). S. 15-17.

5. Natsionalna Dopovid pro stan i perspektyvy rozvytku osvity v Ukraini [National speech about status and strategy of advancement of education in Ukraine]; za zah. red. V. H. Kremenia. Kyiv : Irpin: Pedahihichna dumka, 2016. 448 s.

6. Onats O. M., Kalinina L. M. Kontseptualni zahody orhanizatsiinykh mekhanizmiv i tekhnolohii hromadsko-derzhavnoho upravlinnia [Conceptual basis of the organizing tools and technologies of public state management] : posibnyk / za nauk. red. L. M. Kalininoi. Kyiv : Vydavhychyi dim «Sam», 2017. 64 s.

7. Pastovenskyi O. V. Hromadsko-derzhavne upravlinnia zahalnoiu serednoiu osvitoiu v rehioni [Public-state secondary education management in the region] : avtoref. dys. ... d-ra ped. nauk : 13.00.06. Kyiv, 2015. $44 \mathrm{~s}$.

8. Pro osvitu : Zakon Ukrainy [Law of Ukraine «On Education»] : vid 5 veresnia 2017 r. № 2145. URL: https://zakon.rada.gov.ua/ laws/show/2145-19 (data zvernennia: 17.11.2019).

9. Terminolohichnyi slovnyk z osnovpidhotovky naukovykh ta naukovo-pedahohichykh kadriv pisliadyplomnoi pedahohichoi osvity [Terminological dictionary of basis for preparation scientific and scientific and pedagogical staff of post-qualifying pedagogical education] / za nayk. red. Ye. R. Chernyshovoi. Kyiv : DVNZ «Universytet menedzhmentu osvity», 2014. $230 \mathrm{~s}$.

\title{
Mykhasiuk O. K. Criteria of effectiveness of public-state management of the general educational institutions
}

The article is devoted to substantiating the relevance of introducing the public-state management of general secondary educational institutions. It is caused by the democratization and decentralization processes of management in the field of education.

It is proved, that the effective implementation of this management system requires the determination of appropriate criteria. However, it is very important to use measurements for evaluating their effectiveness, including pedagogical qualimetry. Factor and criterial modelling is chosen as one of these methods, which involves delineation of factors, their division into criteria, establishment of import and values accordingly.

Based on analysis of scientific sources, the criteria of public-state management of general secondary education in the region were chosen by factors and adopted them to the public-state management of general secondary educational institutions system. As a result, information and diagnostic factor includes the following criteria: transparency of educational institution, marketing activity, digitalization of the educational process; integrated and modeling factor: public relations (using of PR-technologies), development of a network of public management bodies and autonomous power, spatial planning; organizational-coordinating factor: organization of the educational process based on public inquiries, resources exploitation by the community, project activities, fundraising, crowdfunding, collaboration with educational institutions, partnership with affairs, institutions, entrepreneurship, accomplishment of the concept of social-minded schools; control-expert factor: quality of educational activities, quality monitoring of education, public inspection; coordinating and corrective factor: satisfaction level of members of educational process and stakeholders, compliance the educational activities organization with societal demands.

In this study we propose an author model of the factorial and criterion evaluation of the development of the public-state management system of general secondary educational institutions. Moreover, we have determined and characterized the levels of its development, namely: high, sufficient medium and low.

Key words: public-state management, criterion, effectiveness, criteria of effectiveness of public-state management of the general educational institutions, pedagogical qualimetry, factorial and criterion modelling, factor.

УДК 373.3.013.43:37.06

DOI https://doi.org/10.31392/NPU-nc.series5.2019.71.39

Молнар T. I.

\section{КРОСКУЛЬТУРНИЙ ПРОСТІР ПОЧАТКОВОЇ ШКОЛИ ЯК СФЕРА ВЗАЕМОДІЇ СУБ'СКТІВ}

Порушується проблема кроскультурного простору початкової школи як сфери взаємодї трьох суб'єктів: педагога, дитини і середовища між ними. На основі аналізу наукової літератури визначено стан досліджуваного питання в педагогічній теорії і практиці; уточнено сутність понять «простір», «освітній простір» «кроскультурний», «кроскультурний простір закладу освіти»; окреслено обставити, які впливають на побудову кроскультурного простору початкової школи; акцентовано увагу на важливості врахування культурно-освітнього потенціалу мікрорайону під час моделювання кроскультурного простору закладу освіти.

3'ясовано, щео сучасна початкова школа розглядається як динамічний кроскультурний простір, мета якого полягає в оптимізації розвивального потенціалу молодших школярів. Під кроскультурним простором початкової школи розуміється вся сукупність освітніх закладів різного типу і виду, суспільних і державних організацій, щзо взаємодіють між собою. Разом вони створюють простір соиіалізації шестирічної дитини, перетворення ії в особистість, забезпечують певний рівень освіти, інтелекту і культури суспільства, міжособистісних, етичних, етнічних $і$ всіх інших відносин.

Встановлено, що можливість побудови кроскультурного простору зумовлена комплексом обставин. По-перше, створення кроскультурного простору початкової школи диктується тими об'єктивними проиесами, щчо відбуваються нині у світовій спільноті, припускаючи необхідність інтеграції всіх сил в освоєнні просторів (інформаційних, технологічних, економічних тошо), що є провідним елементом подальшого прогресу. По-друге, формування кроскультурного простору стимулюється потребою поглиблення відносин взаємодії всіх членів сучасного співтовариства, в реально виниклому прагненні яких до розширення економічних, політичних, культурних та інших зв 'язків освітній простір відіграє важливу роль, оскільки саме тут виявляються тендениії розвитку.

Ключові слова: освіта, культура, простір, освітній простір, кроскультурний, кроскультурний простір закладу освіти, початкова школа. 
Останнім часом у теорії освіти все активніше використовується категорія простору. Простір - це філософська категорія, форма співіснування матеріальних об'єктів і процесів (характеризує структуру і протяжність матеріальних систем). Простір, його вивчення й опис його властивостей в останні декілька століть було монополізоване фізиками. У результаті будь-які дискусії науковців про природу простору рано чи пізно впираються в сучасну фізику. При цьому сучасне наукове співтовариство ігнорує три факти:

1. Простір - це поняття, яке присутнє в мисленні кожної людини, незалежно від віку, статі, ставлення до релігії, національності і ступеня освіти.

2. У математиці слово «простір» використовується в безлічі різних теорій, що не мають ніякого стосунку до фізики.

3. Нарешті, це слово вживається в буденному мовленні: «культурний простір», «економічний простір» тощо.

Філософсько-педагогічний підхід отримав обгрунтовування і розвиток у роботі I. Колесникової [4]. Авторка спирається на філософську природу категорії «простір» і доводить, що його можна співвіднести із феноменом виховання завдяки його онтологічності, убудованості в буття.

Термін «освітній простір» почав використовуватися педагогами, соціологами, управлінцями, політиками на початку 80-х років минулого століття. На початку 90-х дефініція увійшла до широкого наукового обігу, поступово виформовуючись у наукову категорію. Категорія «освітній простір», безумовно, належить до фундаментальних понять сучасної педагогіки [5].

Показово, що сама ідея формування освітнього простору обговорюється досить багатоманітно, на різних рівнях, $\mathrm{i}$, попри це, вона й дотепер не структурована і не оформлена. Характерно, що навіть термін «освітній простір» сприймається неоднозначно.

У науковій літературі, у публіцистиці фігурують поняття «міжнародний», «європейський», «український освітній простір» тощо. Тобто йдеться про освітній простір, що визначається у зв' язку з конкретно-політичними, географічними, економічними та іншими характеристиками. Усі пов'язані з обговоренням освітнього простору визначення замикаються в основному лише навколо конкретних структурно-змістовних моментів, таких як освітні стандарти, норми, вироблення єдиних програм, єдиних вимог, визнання дипломів усіх рівнів тощо.

Спробу розгляду освітнього простору як особливої сфери взаємозв'язків певних компонентів освітньої практики зробив В. Слободчиков [7]. У запропонованій ним моделі «... освітня практика - тепер уже як особлива сфера, як органічне ціле, здатне до розвитку, - виступає в трьох своїх взаємозв'язаних наочних проєкціях (освітні середовища, інститути, процеси) і двох механізмах його забезпечення: освітня політика, що реалізовує функцію самовизначення освіти в соціумі, і управління освітою, яке зміцнює його як цілісну сферу...» (В. Слободчиков, 1995) [7]. На думку відомого науковця, виникає своєрідне середовище, в якому кристалізуються спеціальні структури, покликані організовувати освітній процес, а саме: необхідно вибудовувати іншу низку уявлень, де середовище $є$ середина $=$ серцевина, зв 'язок = середостіння, засіб = посередництво.

Такого роду середовище, як простір дії суб’єктів, виявляючись на різному рівні, у різних формах, забезпечує підстави для добору елементів, необхідних для організації змісту освіти в єдиному освітньому просторі. Це середовище як широкий простір взаємодії припускає можливість дії не тільки державних, але й суспільних структур, тобто створення простору, який забезпечує відкриту систему відносин із практичного вироблення освітніх систем.

Метою статті $\epsilon$ розгляд кроскультурного простору початкової школи як сфери взаємодії трьох суб'єктів: педагога, дитини та середовища між ними.

Ідея середовища - ключова. Освітній простір, з одного боку, це - збалансована мережа закладів освіти та установ, а з іншого - сукупність змістовних просторів (ніш), які опосередковують розвиток особистості. Розгляд моделі створення кроскультурного простору початкової школи не може не грунтуватися на сучасних досягненнях науки і практичних доробках.

Методологічними і теоретичними засадами проблеми, яка заявлена в дослідженні, $\epsilon$ такі:

- основні положення теорії особистісно-зорієнтованої освіти (О. Бондаревська, Є. Гусинський, С. Подмазін, В. Слободчиков, І. Якиманська та інші);

- сучасні концепції розвитку освіти й освітнього простору (В. Воронцова, О. Іванов, Г. Ковальов, В. Козирєв, І. Крупіна, Ю. Мануйлов, В. Лєвін та інші);

- філософсько-педагогічні концепції педагогічного проєктування як методу і технології розвитку освітніх систем (О. Александрова, Е. Заїр-Бек, О. Казакова, Т. Новікова, М. Поташник, В. Родіонов, В. Сєріков та інші);

- концепції педагогічної культури, професійного самовизначення і самореалізації педагога (I. Алексашина, О. Бондаревська, Б. Гершунський, Є. Захарченко, Н. Пряжников та інші);

- сучасні підходи до розуміння сутності феномена дитинства (Ю. Аксьонова, Л. Боровікова, Н. Гавриш, І. Кон, О. Кононко, В. Кудрявцев, Л. Обухова, М. Осоріна, Т. Піроженко, Д. Фельдштейн, Б. Ельконін та інші);

- прикладні дослідження в галузі теорії і практики дошкільної освіти (Т. Алієва, А. Богуш, Л. Кларіна, Т. Комарова, І. Котова, М. Крулехт, В. Кудрявцев, Н. Михайленко, В. Петровський, О. Сафонова, Л. Смивіна, Л. Стрелкова та інші); 
- сучасні українські наукові розвідки: властивості кроскультурного діалогу та особистісного розвитку людини в міжкультурному полілозі (I. Бех), планетарне мислення особистості (Є. Зеленов), чинники іiі соціалізації під впливом світових і планетарних процесів (Н. Сейко), формування кроскультурних цінностей у дітей молодшого шкільного віку (С. Алієва), формування мовної особистості в європейському соціокультурному освітньому просторі (В. Махінов), професійна підготовка студентів до взаємодії (Ф. Асанова, Р. Гришкова, І. Зозуля, Ю. Ірхіна, Н. Калашник, Н. Якса та інші), формування загальнокультурних духовних цінностей (Г. Шевченко).

Передусім, освітній простір є не лише теоретичним поняттям, але й є мовною конструкцією, моделлю, у якій присутні дві субмоделі: освіта і простір.

Усе більше стає зрозумілим, що тільки духовна культура на тлі кроскультурності може врятувати людство від деградації і руйнування (М. Казінік). Кроскультурний розуміється як взаємопроникнення і взаємовплив мовних світів і культур, перетин спільного і відмінного. Тому в новому тисячолітті на зміну людині розумній (Homo Sapiens) повинна прийти людина культурна (Homo Culthuralis). Це буде можливо лише за умов здійснення органічного та діалектичного взаємозв'язку позначеної тріади «культура - освіта - людина», й взаємозв'язок може виявлятися в різних аспектах і вимірюваннях. Зауважимо, що освіта як проміжний член тріади відіграє провідну роль у взаємозв’язку людини і культури. Ще Г. Гегель під терміном «освіта» мав на увазі зміст, близький традиційному застосуванню слова «культура»: у значенні культивування, окультурення людини, а також понять «формування», «формація», «генезис» [8, с. 64].

Відомий методолог у галузі освіти С. Гессен розглядає поняття «освіта» як один із синонімів слова «культура», вважаючи, що це поняття було б правильно закріпити за «духовним змістом культурного життя» [3]. Водночас С. Гессен указував на неправомірність «поглинання» людини культурою. Він говорив про те, що «людина не тільки відтворює минуле, але, розвиваючись сама, розвиває культуру. І в цьому значенні людина і культура - два рівноцінних суб' єкти» [3, с. 54]. У зв'язку з цим буде доречно навести також цитату з роботи Н. Бордовської і А. Реана: «Культура виступає передумовою і результатом освіти людини» [6, с. 62]. Завдяки освіті людина засвоює загальнолюдську культуру та досвід i, навпаки, через освіту вона може їх творити і збагатити. О. Валицька зазначає: «Освіта становить фундамент національної культури, універсальну форму ii існування, спосіб зберігання і відтворювання генофонду і культурного досвіду народу» [1, с. 5]. 3 іншого боку, освіта людини у широкому значенні цього слова є освітою (становленням) в ній людської сутності, що міститься і розкривається в людській культурі, тому що «культура є мірою людського в людині» [7, с. 20].

На думку О. Валицької, «освіта культури і культура освіти взаємообумовлені, це поняття, що пояснюють перше динаміку, друге - якість розвитку суспільства» [1, с. 65]. На нашу думку, цілком доречним у межах дослідження $\epsilon$ вживання поняття «кроскультурність освіти», маючи на увазі два аспекти: висока якість процесу освіти і висока якість його результату або продукту. Ідеальною метою сучасної освіти має виступати «людина культури».

Одним з основних питань сучасної педагогіки, конструктивною відповіддю на яке є сам освітній простір, є питання про зв'язок освіти і культури. Перехід освіти в нове культурне вимірювання підготовлений розвитком сучасного педагогічного мислення. В аспекті цієї проблеми можна виокремити найбільш значущі напрями в педагогіці.

1. Розуміння освіти як культуровідповідного і культуроутворювального простору, малої культури, культурного мікрокосму.

Основи культурологічного підходу до освіти розроблено В. Біблером, О. Бондаревською, О. Газманом, В. Зінченко та іншими.

2. Перехід від знаннєвої до особистісно-розвивальної, особистісно-зорієнтованої парадигми.

Новий підхід до можливостей освітнього процесу формується у зв'язку з проєктуванням, програмнометодичним розробленням й упровадженням систем розвивального навчання В. Давидова, Л. Занкова, Д. Ельконіна. Психолого-педагогічні основи освіти нового особистісно-розвивального типу представлено в роботах К. Крутій, В. Петровського, В. Слободчикова, І. Якиманської та інших. Широку популярність здобули педагогічні концепції особистісно-зорієнтованої освіти О. Бондаревської, З. Кульневича, а також низка концептуальних ідей, які розвиваються Т. Власовою, В. Данільчуком, М. Сергєєвим, Л. Сухоруковою, Р. Чумічовою та іншими вченими.

Однією з ідей нової освітньої ситуації є визнання гуманістичної парадигми освіти, переорієнтація на цінності людини, становлення її як суб'єкта не тільки освітньої діяльності, але й культури. Значна увага у зв'язку з цим надається особистісно-зорієнтованій освіті як особливому засобу розкриття сутнісних сил людини, її здібностей, отримання свого місця в просторі культури.

У контексті нашого дослідження спираємося на розуміння кроскультурного простору як особливого соціокультурного феномена - системи багатопланових і багатовимірних відносин, що об' єктивно відтворюються та самостійно розвиваються в процесі організації і трансляції певної необхідної сукупності знань, яка функціонує в реальному просторово-часовому континуумі та охоплює як суб'єктів взаємодії, так і високу комунікативну здатність, стійкість, мобільність, толерантність.

Розглядаючи кроскультурний простір закладу освіти, закцентуємо увагу, по-перше, на визначенні його як явища сучасного світу; по-друге, на виявленні його особливостей, завдань, можливостей як соціокультурного феномена, що специфічно функціонує. 
Проблема можливості побудови кроскультурного простору зумовлена комплексом обставин. По-перше, створення кроскультурного простору початкової школи диктується тими об'єктивними процесами, що відбуваються нині і у світовій спільноті, припускаючи необхідність інтеграції всіх сил в освоєнні просторів (інформаційних, технологічних, економічних тощо), що $є$ провідним елементом подальшого прогресу. По-друге, формування кроскультурного простору стимулюється потребою поглиблення відносин взаємодії всіх членів сучасного співтовариства, в реально виниклому прагненні яких до розширення економічних, політичних, культурних та інших зв’язків освітній простір відіграє важливу роль, оскільки саме тут виявляються тенденції розвитку.

Природно, можна було б значно збільшити число обставин, що вимагають побудови кроскультурного простору, розширивши їх аналіз. Але для нас важливою є об'єктивна зумовленість ідеї формування кроскультурного простору для дітей шестирічного віку, з’ясування головних умов, характеристик, які, з одного боку, виправдовують цю ідею, а з іншого - задають певні норми і принципи організації цього простору [5].

Кроскультурний простір багатовимірний. Провідним чинником суспільного буття в цьому просторі є культура, яка забезпечує збереження і відтворювання людських ресурсів, культури здоров’я і культури здорового способу життя, культури усвідомлення і вирішень протиріч буття. Кроскультурний простір виформовує єдину націю із загальною назвою, державною (-ними) мовою (-ами), із спільністю культури, із загальною метою і загальними діями щодо їхнього досягнення. В цьому просторі закладаються навички самоорганізації і самоврядування народу, устрою його життя, здійснюється зв'язок поколінь і генеруються нові результати життєдіяльності.

Поки, на жаль, немає загального, чітко науково оформленого визначення кроскультурного простору, так само як не визначено місце, рівні його складників.

Визнаючи цінність аналізованих нами досліджень, зазначимо, що вивчення проблеми побудови кроскультурного простору та його наукові розробки відстають від запитів сучасної практики освіти всіх рівнів.

Кроскультурний простір може розглядатися як сфера взаємодії трьох його суб'єктів: педагога, дитини i середовища між ними. Висновок Л. Виготського про трибічний активний процес (активний педагог, активна дитина, активне середовище між ними) дає змогу розглядати трикомпонентну взаємодію суб'єктів простору як єдиний процес цілеспрямованого формування особистості дитини [2]. У цьому процесі взаємодія суб'єктів освітнього простору, педагога і дитини представлена як активна взаємодія із середовищем, яке можна розглядати як інформаційний компонент освітнього простору, структурованого так, що він сам активно впливає на інших суб'єктів освітнього простору. Ця структура може бути визначена як «ідеальна форма середовища» (Л. Виготський).

Ключовою фігурою в кроскультурному просторі, поза сумнівом, є педагог. Активна взаємодія суб’єктів кроскультурного простору виформовує «середовище спільної діяльності». Отже, відбувається формування й оформлення іiї власної мети як системоутворювального чинника.

Система освіти є активним, провідним компонентом у взаємостосунках з іншими компонентами кроскультурного простору регіону (району, міста) і представлена зв’ язками різного рівня: інформаційними, асоціативними, координаційними, коопераційними.

Кроскультурний простір пред’являє певні вимоги до регіональної (районної, міської) системи освіти. До таких вимог можна віднести урахування: культурно-історичних традицій; сучасного складу, потреб регіональної виробничої сфери; регіонального запиту громадськості. До числа основних характеристик регіональної системи освіти разом із відкритістю відносять територіальність як умову ефективності ії функціонування і розвитку, а також інформатизацію простору.

У процесі вивчення, моделювання, вибудовування кроскультурного простору початкової школи необхідно враховувати специфіку мікрорайону, в якому вона розташована. Матеріали різних досліджень показують, що в місті виокремлюється декілька регіонів, які зумовлюють середовище життєдіяльності школи: осередок із багатими культурно-освітніми традиціями, науковими закладами; великі мікрорайони, на їхній території розташовані підприємства, що визначають усе соціально-культурне середовище; спальні мікрорайони, де школи - єдині осередки культурного життя; мікрорайони з переважанням приватного сектору і відсутністю культурного оточення, населення в них орієнтовано на працю в підсобному господарстві; новобудови, в яких відсутня або не досить розвинена інфраструктура культурно-просвітницьких закладів; мікрорайони з однорідним ізольованим середовищем (військові, академічні містечка тощо).

Дослідження кроскультурного простору в різних мікрорайонах міського осередку (м. Мукачево) дають підстави стверджувати, що він впливає на етичний досвід молодшого школяра, а саме: шестирічки, які мешкають у районах, що історично давно склалися, краще поінформовані, активніше взаємодіють із різними закладами, отже, значну роль у виборі початкової школи відіграє соціокультурне середовище цих мікрорайонів; чим далі розташована школа від культурного осередку, тим активнішою має бути участь дітей у житті національної меншини; знання і врахування культурно-освітнього потенціалу мікрорайону необхідні під час моделювання кроскультурного простору в конкретному закладі.

Отже, під кроскультурним простором початкової школи розуміємо всю сукупність освітніх закладів різного типу і виду, суспільних і державних організацій, що взаємодіють між собою. Разом вони створюють простір соціалізації шестирічної дитини, перетворення її в особистість, забезпечують певний рівень освіти, 
інтелекту і культури суспільства, міжособистісної, етичної, етнічної і всіх інших відносин. У цьому просторі в дітей виформовуються і розвиваються цілісне розуміння світу, світогляд, міцні духовно-етичні засади, уявлення про цінності і значення життя, культура здоров'я і здорового способу життя, чітка мотивація життєдіяльності, культура безпеки тощо.

Висновки. У педагогічній теорії феномен кроскультурного простору розглядається широко - від державного рівня до особистісного, індивідуального простору пізнання і розвитку. Сучасна початкова школа як заклад освіти розглядається як динамічний позитивний кроскультурний простір, мета якого полягає в оптимізації розвивального потенціалу дітей.

\section{Використана література:}

1. Валицкая А. П. Образование в России. Стратегия выбора : монография. Санкт-Петербург : Рос. гос. пед. ун-т им. А. И. Герцена, 1998. С. 5-69.

2. Выготский Л. С. Развитие личности и мировоззрение ребенка. Психология личности : в 2-х т. Т. 2. Самара, 1999. С. $160-165$.

3. Гессен С. И. Основы педагогики. Введение в прикладную философию. Москва : Школа-Пресс, 1996. С. 5-99.

4. Колесникова И. А. Педагогическая реальность в зеркале межпарадигмальной рефлексии. Санкт-Петербург : СПбГУПМ, 1999. $242 \mathrm{c}$.

5. Крутій К. Л. Освітній простір дошкільного навчального закладу : монографія : у 2-х ч. Частина перша. Концепції, проектування, технології створення. Запоріжжя : ТОВ «ЛІПС» ЛТД, 2009. 320 с.

6. Бордовская Н. В., Реан А. А. Педагогика : учебник для вузов. Санкт-Петербург : Питер, 2003. С. $62-67$.

7. Слободчиков В. И., Исаев Е. И. Основы психологической антропологии. Психология человека. Введение в психологию субъективности : учеб. пособие для вузов. Москва : Школа-Пресс, 1995. С. $20-99$.

8. Философский энциклопедический словарь / гл.ред. Л. Ф. Ильичев. Москва : Наука, 1983. 321 с.

\section{References:}

1. Valitskaya A. P. (1998) Obrazovaniye v Rossii. Strategiya vybora : monografiya [Education in Russia. Selection Strategy: Monograph]. Russian State pedagogical university. P. 5-69.

2. Vygotskiy L. S. (1999) Razvitiye lichnosti i mirovozzreniye rebenka. Psikhologiya lichnosti [The development of personality and the worldview of the child. Psychology of personality]. Samara. P. 160-165.

3. Gessen S. I. (1996) Osnovy pedagogiki. Vvedeniye v prikladnuyu filosofiyu. [Fundamentals of pedagogy. Introduction to Applied Philosophy]. School press. P. 5-99/

4. Kolesnikova I. A. (1999). Pedagogicheskaya real'nost' v zerkale mezhparadigmal'noy refleksii [Pedagogical reality in the mirror of interparadigmal reflection]. P. 242.

5. Krutiy K. L. (2009). Osvitniy prostir doshkil'noho navchal'noho zakladu : monohrafiya : u 2-kh ch. Chastyna persha. Kontseptsiyi, proektuvannya, tekhnolohiyi stvorennya [Educational space of a preschool educational institution : monograph: In $2 \mathrm{~h}-\mathrm{Part}$ one. Concepts, design, creation technologies]. Zaporizhya. P. 320.

6. Pedagogika: (2003). Uchebnik dlya vuzov [Pedagogy: Textbook for high schools]. St. Petersburg : Peter. P. 62-67.

7. Slobodchikov V. I. (1995). Osnovy psikhologicheskoy antropologii. Psikhologiya cheloveka. Vvedeniye v psikhologiyu sub'yektivnosti : ucheb. posobiye dlya vuzov [Fundamentals of psychological anthropology. Human psychology. Introduction to the psychology of subjectivity: Textbook for universities]. School press. P. 20-99.

8. Filosofskiy entsiklopedicheskiy slovar' (1983). [Philosophical Encyclopedic Dictionary]. Science. P. 321.

\section{Molnar T. I. Cross-cultural space of primary school as a field of interaction of subjects}

The article has dealt with the problem of the cross-cultural space of primary school as a sphere of interaction between three subjects: the teacher, the child and the environment. On the basis of the scientific literature analysis the state of the investigated issue in pedagogical theory and practice has been determined; clarified the sense of the conceptions «space», "educational space» "cross-cultural», "cross-cultural space of educational establishment»; outline the factors that influence the construction of the cross-cultural space of primary school; the attention has been paid to the importance of taking into account the cultural and educational potential of the neighborhood when modeling the cross-cultural space of an educational establishment.

It has been found that the modern primary school is considered as a dynamic cross-cultural space, the purpose of which is to optimize the developmental potential of younger students. The cross-cultural space of primary school refers to the whole set of educational establishments of various types and kinds, public and state organizations that interact with each other. Together, they create the space for socializing a six-year-old children, transforming them into personality, providing a certain level of education, intelligence and culture of society, interpersonal, ethical, ethnic and all other relationships.

It has been established that the possibility of constructing a cross-cultural space is conditioned by a set of circumstances. Firstly, the creation of the cross-cultural space of primary school is dictated by the objective processes that are taking place in the world community today, assuming the need to integrate all forces in the development of space (information, technological, economic, etc.), which is a leading element of further progress. Secondly, the formation of cross-cultural space is stimulated by the need to deepen the relations of interaction of all members of the modern community, in whose real desire to expand economic, political, cultural and other ties the educational space plays an important role, because it is here that trends are manifested.

Key words: education, culture, space, educational space, cross-cultural, cross-cultural space of educational establishment, primary school. 